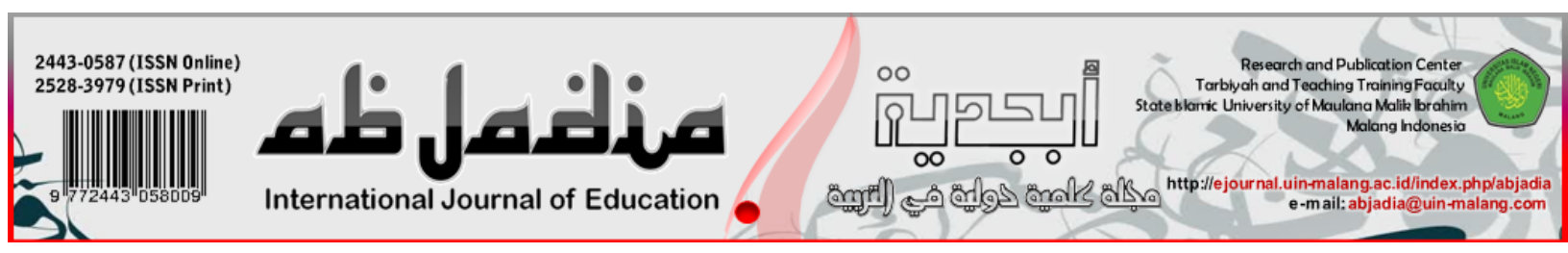

\title{
MASS COMMUNICATION EDUCATION FOR RADIO MOSQUE MANAGERS IN DATING HOAX AND RADICALISM NEWS
}

\author{
Muhammad In'am Esha 1, R. Taufiqurrochman 2, Dewi Nur Suci ${ }^{3}$ \\ 1,2 Universitas Islam Negeri Maulana Malik Ibrahim Malang, Indonesia \\ ${ }^{3}$ Institut Agama Islam Negeri (IAIN) Kediri, Indonesia
}

Article History:

Received : 2019-12-26

Revised : 2019-12-29

Accepted : 2019-12-30

Published : 2019-12-31

\section{Keywords:}

Mass Communication, Radio Mosque, Hoax, Radicalism

Correspondence Address: muhammadinamesha@gmail.com taufiq@uin-malang.ac.id dewinursuci@gmail.com

\begin{abstract}
The news hoax and radical understand like a chain that is not separated. Both are very dangerous and have the potential to damage the unity and integrity of the nation and state. This concern encourages researchers to conduct research and assistance for mosque media managers. The sample in this study was the manager of Radio el-Jannah 100.9 FM Malang. This research uses a qualitative approach with four stages: data collection, training, assistance and evaluation. The results of this study indicate that the function of the mosque remains as a centre for community empowerment so that it needs to have communication media, one of which is a radio which still has a loyal audience segment. The manager of the mosque radio must master the skills of mass communication so that the viewers can thoroughly receive the message broadcast because from the results of this study it was found that the manager of the mosque's radio had never learned about mass communication. Message and receiver broadcast material must be valid, selected, and aimed at educating the public to ward off hoax news and radical understanding.
\end{abstract}

\section{(C) Introduction}

The mosque not only functions as a place of worship but also as a centre for the empowerment of the people and a role in building human civilization. Therefore, the mosque's role is to convey true and educational information, as well as being able to ward off false information and hoax news that now threatens the integrity of the people and national unity. This is what drives mosque managers to provide public information media by utilizing various print and electronic media such as radio, television, internet, magazines, bulletins, and so on.

One of the mosques which have media in the form of radio is the Muritsul Jannah mosque in Kotalama Malang. The mosque radio called el-Jannah 100.9 FM has become the pride of the mosque manager and the surrounding community because this radio does not only broadcast religious material, but also information about citizens' activities, business info, and so on. (Rahman, 2018) The problem is that the radio el-Jannah 100.9 FM is still newly formed, since 2018 so that the managers of the radio El-Jannah $100.9 \mathrm{FM}$ feel the need to improve their ability in mass communication so that messages conveyed 
through radio broadcasts become valid, accurate, reliable, informative, interactive and that the most important thing is being able to filter out hoax news that is widely circulating in the community.

Lately, a hoax has spread massively in the community. This is a concern for the Takmir Mosque of Muritsul Jannah Malang, so he hopes that the El-Jannah 100.9 FM radio will be able to educate the public. This concern is in line with the results of the 2017 Telematics Society survey (Mastel) which states that people's behaviour when receiving hoax news, they accept it and even continue or spread the news to other parties so that the hoax continues to spread like a deadly virus. (Mastel, 2017)

This hoax news phenomenon is also supported by a feeling of pleasure in the community in receiving new information. This trait is easily deceived by the constant news of hoax spread by irresponsible parties. (Santhika, 2017) The Paw Research Center said in its research results, out of 1002 respondents, as many as 23 per cent of adults claimed to have shared information or news that they still doubted was accurate. (Research Center, 2010) This shows that even adults who have an understanding are sometimes ignorant or don't pay attention to a hoax. It is not impossible that this also happens in the mosque and the community around the mosque.

In addition to hoax news, radical understanding is also a problem that needs to be addressed by mosque management because based on the results of a survey of the State Intelligence Agency (BIN), 41 out of 100 mosques in ministries, institutions and stateowned enterprises are exposed to radicalism. LibForAll Foundation research results (2009) mentioned that hardline Islamic groups have now controlled hundreds of mosques in Indonesia which were initially the basis of the spread of moderate Islamic values. They made the mosque a sign of movement and propaganda. Therefore, the National Counterterrorism Agency (BNPT) asks mosques not to be misused to spread ideas that are contrary to state ideology. (Don, 2019)

Hoax news spread and radical understanding like links. News hoax can cause news recipients to become radical; on the other hand, and extreme knowledge can quickly spread along with the spread of news hoax that is readily accepted by the public through various mass media. (Winarni, 2014) The mosque, as a centre for the development of the people, must be able to overcome these two problems. The mosque must straighten out the news that is not true and should not be used as a sign of the spread of radicalism. Therefore, mosques must-have media that can convey messages to the public, both print, electronic, and so on.

The radio manager of the el-Jannah 100.9 FM mosque felt that it needed an increase in skills in the field of mass communication to overcome the spread of hoax news and ward off radical understanding. Therefore, the research team conducted assistance to research to train the skills of mosque radio managers about mass communication. This research takes place intensively by presenting relevant material related to the science of transmission, broadcasting, mass psychology, techniques to detect hoax news and ward 
off radical notions that lead to extremism.

This article describes the assistance process, and the results of research on mass communication education applied explicitly to the mosque radio manager. The research team hopes the results of this study can be transformed and used in other mosques that have public information media, especially radio.

\section{$\mathbb{Q}$ Theoretical Support}

\section{Mass Communication}

Mass communication is a communication process carried out through mass media with various communication purposes and to convey information to a wide audience. By this definition, it means that there are six elements of mass communication, namely: communicators, mass media, information or messages, gatekeepers or information selectors, public or public, and feedback. (Mulyana, 2016) Communication is understood as a human process responding to the symbolic behaviour of others. Communication that occurs in humans takes place at various levels of communication. Starting from intrapersonal communication, interpersonal communication, group communication, public communication and mass communication. (Watie, 2011)

Mass communication consists of messages that are transmitted to a large and wideranging audience, using newspapers, newspapers, magazines, radio, television and the internet.(Adler \& Rodman, 2006; Cangara, 2005) So it can be said, the media used in conveying messages in mass communication are called mass media. The condition of mass communication can be found in social media because many people can see the news delivered by someone in social media, so that mass communication occurs.

The same condition is also found in radio media so that the radio's position becomes part and mass media and belongs to the public. The location of this radio can be said to be the same as the position of the mosque also belongs to the masses; even the community feels they have it. The sense of community concern for the mosque and all media owned by the mosque certainly has a positive impact in establishing communication between the messenger (mosque radio) and the recipient of the message (community).

The functions of mass communication are information, entertainment, persuasion, cultural transmission, encouraging social cohesion, supervision, correlation, social inheritance, against power and repressive forces. (Nuruddin, 2013) Mass communication media provide cognitive, affective, and behavioural effects. Cognitive effects occur when there are changes in what is known, understood, or perceived by the public. This effect is related to the transmission of knowledge, skills, trust or information. Affective outcomes will arise if there is a change in what is felt, liked or hated by the public. This effect has to do with attitudes, emotions, or values. Behavioural effects refer to real behaviours that can be observed, including patterns of actions, activities, or behavioural habits. (Rakhmat, 2011) For example, after hearing an interactive dialogue about 
Moderate Islam over the radio, information might be obtained about the nature of Moderate Islam (cognitive effects), or there may be a feeling of emotion witnessing the success of Moderate Islam (affective impact) so that it follows the teachings of Moderate Islam and away from radicalism (the effect of behavioural).

\section{Hoax News}

Hoax is the biological child of post-truth (Haryatmoko, 2017; Ulya, 2018). Post-truth is described as a time that tends to ignore facts and truths, while hoax can be interpreted as false news or information. The problem with society is not how to get news, but the lack of ability to digest correct details. The credibility of the mainstream media, which is always undermined by the interests of the elite and owners, forces the public to look for alternative information (Syuhada, 2018). The gap between the lack of media literacy in this flood of information is misused by some groups to produce unconfirmed news, which is not necessarily right or often called a hoax. Social media has become an essential medium for spreading hoax (Figueira \& Oliveira, 2017; Grech, 2017).

Hoax news or hoax, actually not new. Hoax and their distribution are regulated in Law of the Republic of Indonesia Number 11 of 2008 concerning Information and Electronic Transactions. In Article 28 Paragraph 1 it is explained that each person intentionally and without the right to spread false and misleading news that results in losses, shall be sentenced to a maximum imprisonment of 6 (six) years and/or a maximum fine of Rp1,000,000,000.00 (one billion rupiahs). (Nugraha \& Sastromiharjo, 2018) Therefore, as social media users, we must be wise and be able to sort and select the information that is received and most importantly not as long as we share/pass on information that is not necessarily true to others. In addition to legal action against hoax spreaders, a method is needed that will enable mosque radio and takmir viewers to process information correctly and adequately

\section{[Q] Method}

This study is qualitative research because it aims to understand the phenomena experienced by research subjects related to mass communication carried out by the managers of Radio el-Jannah 100.9 FM. This type of research is field research because the research team is directly present in the field and liaise with respondents to obtain comprehensive data. (Sugiyono, 2016)

In its implementation, the research team also acted as a companion team to educate radio managers about effective mass communication. The involvement of the research team in the mentoring and training is by the wishes of the Takmir Muritsul Jannah Mosque Malang so that the HR manager of Radio El-Jannah 100.9 FM is increasing. (Atmodirio, 1993)

The approach used is a case study by exploring real activities in the form of radio shows and material to obtain complete data by involving various sources of information 
through interviews, observations, moderate Islamic content, audio material and various related documents. (Creswell, 2015)

The focus of this research is a) the place is the Radio el-Jannah 100.9 FM studio located at Muritsul Jannah Mosque Malang City, East Java, Indonesia; b) the actor is the manager of Radio el-Jannah FM and the management of the mosque's takmir; c) activities are activities that are related to the moderate Islamic de-radicalization and socialization program through mosque radio. This research was conducted for approximately five months, from July to November 2018. Data sources are grouped into two types; primary data and secondary data. Primary data is data obtained by the research team from the community through interviews, observations, Forum Group Discussions (FGD), and so forth. Secondary data is data collected from other information such as the geographical location of the mosque, historical review, social conditions of the community and infrastructure. (Arikunto, 2010)

Data search techniques use structured interviews, observations, questionnaires and documentation of notes, website pages, and audio-visual media. In systematically analyzing the data, the research team followed the inductive qualitative analysis flow compiled by Mc Millian and Scumacher (2001).

The technique of conducting mass communication education and training conducted by researchers is through participatory accompaniment and incentive training held for approximately five months. The first month, the research team did the data collection. The second and third months, the research team conducted education and training. The fourth month, the research team assisted. The fifth month, an evaluation of the achievements controlled by the managers of Radio el-Jannah 100.9 FM and all those involved in broadcasting.

\section{Result}

\section{Radio el-Jannah FM}

"Spreading Wisdom, Reaching Heaven" is the slogan of Radio El-Jannah 100.9 FM. This radio has been initiated since 2017 as a medium for education, propaganda, communication and work. The purpose of the establishment of Radio el-Jannah 100.9 FM is to prosper the mosque by broadcasting moderate Islamic teachings and publicizing the potential of the younger generation in educating the life of the nation and solving the problems of the people to reach the paradise of Allah and His pleasure.

El-Jannah FM Radio's vision is to become the leading mosque-based broadcasting and publication media and to become a pilot in the city of Malang. Radio el-Jannah FM has four missions, namely: a) Da'wah, preaching moderate Islam which spreads mercy to the universe; $b$ ) Friendship, becoming a relationship with various groups and fostering interactive communication; c) Potential, displaying the potential of the younger generation and solving problems faced by the people; d) Education, helps the 
government educate the life of religion, nation and state.

The El-Jannah 100.9 FM Radio Organization consists of a) The Head of El-Jannah 100.9 FM Radio who is responsible for all mosque radio activities; b) Administration, consisting of secretaries and treasurers who manage administrative, financial, documentation, and reporting matters; c) Content and Maintenance, organizing event material, resource persons, reporters, equipment and maintenance of mosque equipment and studios; d) Public Relations, tasked with getting advertisements and establishing cooperation.

Technically, Radio el-Jannah 100.9 FM with 150 watts of power with a frequency of 88-108 Mhz. Geographically, radio coverage reaches more than $20 \mathrm{~km}$. Because the position of the mosque is in the middle of the city, it can be ascertained that all citizens of Malang can enjoy the broadcast of Radio el-Jannah 100.9 FM. Inside the studio, there is a computer, a broadcast table, an interactive dialogue table, a microphone and an adequate sound system. The broadcast time is every day from 4 am to $12 \mathrm{pm}$.

\section{Radio el-Jannah 100.9 Program}

At the beginning of the researcher's presence, the program owned by Radio elJannah 100.9 FM was only about broadcasting mosque activities such as Friday sermons, routine recitation, recitation of the blessings of the prophet, and activities of Islamic holidays. All of these activities are broadcast via radio, both live (live) and through replay (replay). In broadcasting, the researchers found that radio managers also delivered actual news such as sad news, important events such as politics and economics, and other information related to community activities such as community service information, invitations to attend village events, wedding congratulations, and so on.

The problem that the researchers found was that there was news about politics conveyed by radio managers. The story is broadcast without conducting a preliminary analysis of the truth of the press, the source of the report, its benefits and impact on the viewer. In addition to politics, the researchers also found some study material that was broadcast, not through a selection of recitation sources, recitation material which sometimes contained hate speech and hoax. This has encouraged researchers to conduct education and training on mass communication.

At present, El-Jannah FM Radio programs are well-structured and varied, including a) mosque programs; broadcast all religious and educational activities held at the Muritsul Jannah Mosque, both directly and postponed, such as regular recitation, Khatmil Quran, activities of Islamic and national holidays, and so on; b) citizens' activities; broadcasting citizens' events such as community service, mass treatment, sad news, training, and so on; c) potential and products; publicizing the potential of mosque worshipers and residents through product advertisements, service advertisements, and so on; d) interactive communication, greeting people through question and answer with a variety of themes. 
Some of El-Jannah FM's flagship programs are Majelis Ta'lim On Air (Islamic Board of On-Air), Dialog Islam Ramah (Friendly Islamic Dialogue), Akhlaq Nabawi (The Morality of The Prophet), Sinau Bareng (Studying Together), Remas Corner, Ide Bisnis (Business Ideas), Liputan Kampung (Village Coverage), and Info Religi (Religious Info). These programs present competent figures and speakers in their fields. All events are carried out by young people because takmir and the manager of El-Jannah FM Radio involve all members of the mosque's youth to be active.

\section{Mass Communication Education}

Mass communication education material delivered by the resource person or research team are: 1) Basics of mass communication, 2) Technical radio broadcasting, 3) Psychology of mass, 4) Urgency of new filters and information sharing, 5) Moderate Islam and Radicalism. The process of implementing mass communication education is carried out in the form of workshops and Group Discussion Forums (FGD). The research team also presented competent speakers in their fields, especially about Moderate Islam and Radicalism. The research team collaborated with the preachers or religious teachers who are members of LDNU Kedungkandang Malang.

The purpose of Mass Communication Education by training, mentoring and developing human resources for the radio managers of the el-Jannah 100.9 FM mosque is:

a. Renew an individual's expertise in line with needs, viral issues, the threat of hoax news and radical understanding, and technological change. Through mass communication education, trainers can ensure that each individual effectively addresses existing problems and skillfully uses new technology to increase his productivity.

b. You are reducing the learning time of a new individual to become competent at work.

c. Help solve problems quickly and precisely.

d. Orient, each individual towards the organization.

e. Provide a higher ability to carry out tasks so that the results achieved will be maximal.

f. Increase the professionalism of the el-Jannah radio managers 100.9 FM in doing their work.

Stages of Mass Communication Education consists of:

a. Determination of Needs; the purpose of determining the training, mentoring and human resource development needs of the managers of Radio el-Jannah 100.9 FM is to collect as much relevant information as possible to find out the data.

b. Designing the Program; the accuracy of the training methods and assistance for the managers of Radio el-Jannah 100.9 FM depends on the objectives to be achieved. 
Program design starts with identifying what the managers want.

c. Effectiveness Evaluation; the training, assistance and development of human resources of the managers of Radio el-Jannah 100.9 FM must be an appropriate solution to the problems of the mosque and the people, namely to ward off news hoax and radical understandings. The purpose of this stage is to test whether the program is effective in achieving the stated goals.

The participants of this mass communication education were the radio managers and teenagers of the Muritsul Jannah Mosque in Malang as many as 20 people. From the data the researchers found, these participants had never before received training in mass communication. They responded enthusiastically to this workshop. The proof, from the five workshops, held, not one participant was absent. They actively participate in training. Of the 20 participants, only five had attended college. The other 15 people are high school graduates. Of the 20 participants, 50\% had studied at a pesantren, 50\% had never studied at a pesantren and only considered religious knowledge in the village.

Of the 20 participants, all $(100 \%)$ internet users. They claim to receive information from the internet and social media often. They also confessed, rarely analyzed to filter and examine the truth of the news they received. Some members of the mosque's youth claimed to share often the story they got without first reading and finding out the reality of the report. They also claimed that the Koran recitation sources did not convince them that they often heard from the internet or other mass media so that they could not distinguish between moderate speakers and those who were radical.

From the audience aspect, based on interviews and documentation, the research team concluded that the radio audience of El-Jannah 100.9 FM was very diverse, ranging from children, adolescents and adults. They are not only the community around the mosque but also from outside the area. This is because radio broadcasts can be reached from a distance of 20 kilometres. That is, almost all areas in the city of Malang can be reached by broadcasting Radio el-Jannah 100.9 FM. From the results of random interviews with radio viewers, it was found that the most popular program was a live broadcast of religious activities held at the mosque. They also like to follow interactive dialogues and new information related to news that is being viral in the community.

\section{jịis Discussion}

After conducting research and assistance, researchers can conclude several things related to mass communication education for mosque radio managers to ward off hoax news and radical understanding.

First, the mosque still has a vital role as a centre of community activity and information delivery. Therefore, mosques need to have mass media or media that can communicate with the public, such as radio, television, internet channels, bulletins, and so on. These media have a significant impact on educating the community and 
establishing communication links between the mosque and the community.

Second, mosque radios such as Radio el-Jannah 100.9 FM have a positive influence in broadcasting religious teachings and establishing communication with the community. Even though radio broadcasting technology is now almost abandoned by the community because they have switched to internet media, radio still has its segment whose viewers are very loyal and loyal to the radio broadcasts they like, let alone mosque radio. They still exist and follow interactive dialogues broadcast by mosque radio.

Third, assistance and training efforts for mosque radio managers are needed to increase their human resources. Moreover, in the field of mass communication because communication skills are essential in the use of media. As well as the material and media, if the manager does not have qualified skills, then the content and the media will not have a positive influence in educating religious life, nation and state.

Fourth, the material on mass communication must be delivered by resource persons who are competent in their fields. Therefore, the resource persons and assistants should be practitioners who have experience in broadcasting in the mass media.

Fifth, there needs to be a blueprint for managing mosque media such as Radio elJannah 100.9 FM. With a reliable and measurable plan, media management will be more professional and can be carried out quickly and systematically by the organizational structure. Each manager understands the main tasks and works according to the instructions that have been agreed upon.

Sixth, the phenomenon of the spread of hoax news and radical understanding must be a concern of all parties. This challenge is not only the duty of the government and the ulama but also society. The public must be educated to be able to distinguish between true and false news. Gradually, they must also be pro-active by giving a warning to media managers (radio) so that they are not easy to convey unclear information, and the source of information is unclear.

\section{Conclusion}

The mosque as a centre for community empowerment needs to have communication media, one of which is the radio which still has a loyal audience segment. Mosque radio managers must master mass communication skills so that viewers can well receive messages broadcast. The message and material in the radio broadcast must be valid and aim to educate the public. This is important in the midst of widespread hoax news and the spread of radical understanding. The news hoax and radical understand like a chain that is not separated. Both are very dangerous and have the potential to damage unity and integrity. Therefore, intensive assistance is needed so that the mosque media can educate religious, national and state life.

\section{Acknowledgement (optional) / شكروتقدير (إختياري)}

Thank you to the Ministry of Religion of the Republic of Indonesia, Takmir Muritsul Jannah Kotalama Malang Mosque, Manager of El-Jannah Radio 100.9 FM, and the people in the Kebalen area of Kotalama Malang. 


\section{Bibliography}

Adler, R. B., \& Rodman, G. (2006). Understanding Human Communication. New York: Oxford University Press.

Atmodirio, S. (1993). Manajemen Training. Jakarta.

Cangara, H. (2005). Pengantar Ilmu Komunikasi. Jakarta: Raja Grafindo Persada.

Don, K. S. (2019). BNPT Imbau Pengurus Masjid Tangkal Penyebaran Paham Radikal. Accessed from 21 Oktober 2019, dari SINDOnews.com website:

https://nasional.sindonews.com/read/1383699/14/bnpt-imbau-pengurus-masjidtangkal-penyebaran-paham-radikal-1551660263

Figueira, Á., \& Oliveira, L. (2017). The Current State of Fake News: Challenges and Opportunities. Procedia Computer Science, 121, 817-825. https://doi.org/10.1016/j.procs.2017.11.10 6

Grech, V. (2017). Fake news and post-truth pronouncements in general and in early human development. Early Human Development, 115, 118-120. https://doi.org/10.1016/j.earlhumdev.201 7.09.017

Haryatmoko. (2017). Ketika Emosi Dominasi Politik. Accessed from Kompas.Id website: https:/ / kompas.id/baca/opini/2017/11/15/ ketika-emosi-dominasi-politik/

Mastel. (2017). Hasil Survey MASTEL Tentang Wabah Hoax Nasional. Accessed from http:/ / mastel.id/infografis-hasil-survey-mastel-tentang-wabah-hoax-nasional/

Mulyana. (2016). Komunikasi Massa: Fungsi dan Peran. Accessed from https://mercubuana.ac.id/files/SosiologiKompunikasi/Modul-03-.pdf

Nugraha, A. R., \& Sastromiharjo, A. (2018). Gerakan LIterasi Media di Sekolah sebagai upaya meminimalisir Penyebaran Hoaks melalui Media Massa. Peranan Bahasa Indonesia sebagai Literasi Peradaban, 63-72. Accessed from http:// proceedings.upi.edu/index.php/riksabahasa

Nuruddin. (2013). Pengantar Komunikasi Massa, Jakarta. Jakarta: Raja Grafindo Persada.

Rahman, F. (2018). Visi Misi el-Jannah 100.9 FM. Dalam Program Interaktif Umat. Malang.

Rakhmat, J. (2011). Psikologi Komunikasi. Bandung: Remaja Rodaskarya.

Research Center, P. (2010). Millennials: A Portrait of Generation Next. Confident, Connected, Open to Change. Accessed from http://www.pewresearch.org/millnennials

Santhika, E. (2017). Alasan Hoaks Mudah Tersebar di Indonesia. Accessed from https://www.cnnindonesia.com/teknologi/20171019112305-185-249426/alasan-hoaxmudah-tersebar-di-indonesia

Sugiyono. (2016). Metode Penelitian [Research Methods]. Bandung: Alfabeta.

Syuhada, K. D. (2018). Etika Media di Era “Post-Truth.” Jurnal Komunikasi Indonesia, 6(1), 75-79. https://doi.org/10.7454/jki.v6i1.8789 
Ulya, U. (2018). Post-Truth, Hoaks, dan Religiusitas di Media Sosial. Fikrah, 6(2), 283. https:/ / doi.org/10.21043/fikrah.v6i2.4070

Wahid, A. (2009). Ilusi Negara Islam: Ekspansi gerakan Islam transnasional di Indonesia. Jakarta: Gerakan Bhinneka Tunggal Ika, the Wahid Institute, Maarif Institute.

Watie, E. D. S. (2011). Komunikasi dan Media Sosial (Communications and Social Media). The Messenger, III(1). Accessed from http://journals.usm.ac.id/index.php/themessenger/article/view/270/172

Winarni, L. (2014). Media Massa dan Isu Radikalisme Islam. Jurnal Komunikasi Massa, 7(2), 159_ 166.

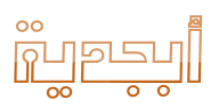

